\title{
Prioritisation and Localisation of Sustainable Development Goals (SDGs): Challenges and Opportunities for Bulawayo
}

\author{
Vinnet Ndlovu ${ }^{1}$, Peter Newman ${ }^{1} \&$ Mthokozisi Sidambe ${ }^{2}$ \\ ${ }^{1}$ Curtin University Sustainability Policy Institute (CUSP), Curtin University, Perth, Australia \\ ${ }^{2}$ Principal Development Consultant, Monte View (Pty) Ltd., Pretoria, South Africa \\ Correspondence: Vinnet Ndlovu, Curtin University Sustainability Policy (CUSP) Institute, School of Design and \\ the Built Environment, Curtin University, Australia. Tel: 61-4-5704-6876. E-mail: \\ vinnet.ndlovu@postgrad.curtin.edu.au
}

Received: August 19, 2020

doi:10.5539/jsd.v13n5p104

\begin{abstract}
Cities are engines of socio-economic development. This article examines and provides insight into the extent of localisation of the UN's Sustainable Development Goals (SDGs) using the City of Bulawayo (CoB), in Zimbabwe, as the case study. The key question posited is 'Does Bulawayo demonstrate potential for sustainable development?' Bulawayo is a strange case study as in the period of the Millennium Development Goals Zimbabwe had a massive increase in death rates from 2000 to 2010 due to the HIV pandemic, political chaos and economic disintegration of that period. Coming out of that period there was little to help cities like Bulawayo grasp the opportunity for an SDG-based development focus. However, after the paper creates a multi-criteria framework from a Systematic Literature Review on the localisation of the SDG agenda, the application to Bulawayo now generates hope. The city is emerging from the collapse of the city's public transport and water distribution systems, once the envy of and benchmark for many local authorities in the country, and has detailed SDG plans for the future. Bulawayo now serves as a planning model for localisation of sustainable development goals.
\end{abstract}

Keywords: localisation, operationalisation, urbanisation, Covid-19, leapfrogging, sustainability

\section{Introduction}

Since the adoption of the UN's Sustainable Development Goals (SDGs) in 2015, there is a strong need for localisation of the global development agenda (UN, 2015). Given the plethora of challenges facing cities in developing countries, including the ongoing pressure from COVID-19, no city can afford to ignore or delay aligning its development trajectory to the SDGs. This paper provides an overview of SDGs and how they apply to cities and creates a framework for evaluating how a city can localise the SDGs. The framework is then applied to the context of Bulawayo to evaluate the potential of the City to develop sustainably. Furthermore, it seeks to understand some of the key challenges and opportunities towards the transition to a sustainable city.

\subsection{Cities in the Context of Sustainable Development Goals (SDGs)}

SDGs articulate a post 2015 global development agenda; they superseded the Millennium Development Goals (MDGs). The global development agenda is encapsulated in 17 goals emanating from consensus of 193 UN member states. Municipalities, through entities with specific focus on local government (e.g. the United Cities and Local Governments [UCLD]) participated in the formulation of the SDGs. SDG 11: 'Make cities and human settlements inclusive, safe, resilient and sustainable', specifically relates to and places cities as the footstool for sustainable human development and progress (Table 1). The centrality of cities towards the future that humanity is thriving for in the context of SDGs is summed up in the statement "The future we want includes cities of opportunities for all, with access to basic services, energy, housing, transportation and more”, (United Nations, 2015). 
Table 1. Sustainable development goal 11

\begin{tabular}{lll}
\hline SDG & Indicator & Target \\
\hline 11.1 & $\begin{array}{l}\text { Ensure access for all to adequate, safe and affordable housing and basic services, and upgrade } \\
\text { slums. }\end{array}$ & 2030 \\
\hline 11.2 & $\begin{array}{l}\text { Provide access to safe, affordable, accessible and sustainable transport systems for all, } \\
\text { improving road safety, notably by expanding public transport, with special attention to the } \\
\text { needs of those in vulnerable situations, women, children, persons with disabilities and older } \\
\text { persons. }\end{array}$ & \\
\hline 11.3 & $\begin{array}{l}\text { Enhance inclusive and sustainable urbanization and capacities for participatory, integrated } \\
\text { and sustainable human settlement planning and management in all countries. }\end{array}$ & 2030 \\
\hline 11.4 & Strengthen efforts to protect and safeguard the world's cultural and natural heritage. & 2020 \\
\hline 11.5 & $\begin{array}{l}\text { Significantly reduce the number of deaths and the number of people affected and } \\
\text { substantially decrease the direct economic losses relative to global gross domestic product } \\
\text { caused by disasters, including water-related disasters, with a focus on protecting the poor and } \\
\text { people in vulnerable situations. }\end{array}$ & \\
\hline 11.6 & $\begin{array}{l}\text { Reduce the adverse per capita environmental impact of cities, including by paying special } \\
\text { attention to air quality, municipal and other waste management. }\end{array}$ & 2030 \\
\hline 11.7 & $\begin{array}{l}\text { Provide universal access to safe, inclusive and accessible, green and public spaces, } \\
\text { particularly for women and children, older persons and persons with disabilities. }\end{array}$ & 2030 \\
\hline $11 . a$ & $\begin{array}{l}\text { Support positive economic, social and environmental links between urban, peri-urban and } \\
\text { rural areas by strengthening national and regional development planning. }\end{array}$ & 2020 \\
\hline $11 . b$ & $\begin{array}{l}\text { By 2020 substantially increase the number of cities and human settlements adopting and } \\
\text { implementing integrated policies and plans towards inclusion, resource efficiency, mitigation } \\
\text { and adaptation to climate change, resilience to disasters, develop and implement in line with } \\
\text { the forthcoming Hyogo Framework holistic disaster risk management at all levels }\end{array}$ & 2030 \\
\hline $11 . c$ & $\begin{array}{l}\text { Support least developed countries, including through financial and technical assistance, for } \\
\text { sustainable and resilient buildings utilizing local materials }\end{array}$ & 2020 \\
\hline & & \\
\hline
\end{tabular}

Notwithstanding the direct relevance of SDG 11, other SDGs are critical towards the development and prosperity of cities. Table 1 highlights the SDG 11 targets that are most directly related to cities. These targets might not explicitly mention cities, but urban policy, strategy and development actions are implied. At the least, cities are instrumental towards the realisation of the targets.

Localisation entails making the intentions of the SDGs resonate with local contexts. Countries and key role players are expected and encouraged to ensure local specific prioritisation of SDGs, and even support local authorities to adapt global targets to local conditions. Localisation of SDGs are crucial due to different contexts, some come from extreme poverty and some are wealthy so there will be a big difference in how they need to prioritise their approaches. Most municipalities in developing countries are still struggling with the provision of basic infrastructure and in this case study on Bulawayo that is clearly the case as will be outlined below. Failure to operationalise SDGs through clear planning directives, as happened during the advent of the MDGs, will lead to perpetuation of poverty and vulnerabilities of most cities in developing countries. In essence, urbanisation is a major tool in achieving the SDG's but without good planning cities will gradually have their urbanisation reversed due to the collapse of services. This will be demonstrated below in Zimbabwe where semi-rural societies within an urban context were starting to dominate Zimbabwe's landscape as development failed and cities began to depopulate (Kamete, Sidambe, \& Ndubiwa, 2000). Only a clear grasp of SDGs, and their localisation (a process to be championed by both political leaders and planning staff) and their operationalisation (which includes sustainable funding models) can help to propel sustainable urban development.

This article attempts to provide answers or shed light to the following key questions and issues:

1) Can Bulawayo develop sustainably, as per the Sustainable Development Agenda? If so, what progress has been made by the City of Bulawayo (CoB) towards localisation of such an approach to development (articulated through the Sustainable Development Goal 11)? 
2) What constraints, if any, impede the operationalisation of the SDGs by the municipality?

3) Can Bulawayo demonstrate the reversal of urbanisation through localised planning for the SDGs?

The main benefits to be derived from the case study are to identify the factors/elements that municipalities can leverage on for effective operationalisation of the SDGs and thus make sustainable development a reality, especially in a developing city context.

\section{Background and Contextual Analysis}

There has been an intense focus on sustainable development since the work by the UN Commission on Environment and Development and their ground-breaking publication "Our Common Future", also commonly referred to as the Brundtland Report (1987). The notion of sustainable development was not immediately applied to cities but it soon grew through activities such as UN Habitat, Local Agenda 21, and ICLEI in the 1990's (Peter Newman \& Kenworthy, 1999). It then followed in the $21^{\text {st }}$ century into The New Urban Agenda (UN-Habitat, 2016) and the Sustainable Development Goals (SDGs) with SDG 11 on cities (UNSDGs, 2015). This paper seeks to look at how the sustainable development concept and especially how the SDG 11 with its clearly enunciated performance indicators, can be taken up in developing cities, with a case study of Bulawayo, Zimbabwe.

Bulawayo inherits its name from the roots of the Ngunis who formed the Mthwakazi Kingdom in the early $19^{\text {th }}$ century. The city became the capital of the Mthwakazi Kingdom and was the main industrial city of Southern Rhodesia in the colonial era. Bulawayo (Map 1) is located on the main train line built to link Cape Town to Cairo. It has a strong history in urban planning as a city that was designed to be a model for development in Africa (Mbiba Beacon \& Ndubiwa Michael, 2008).

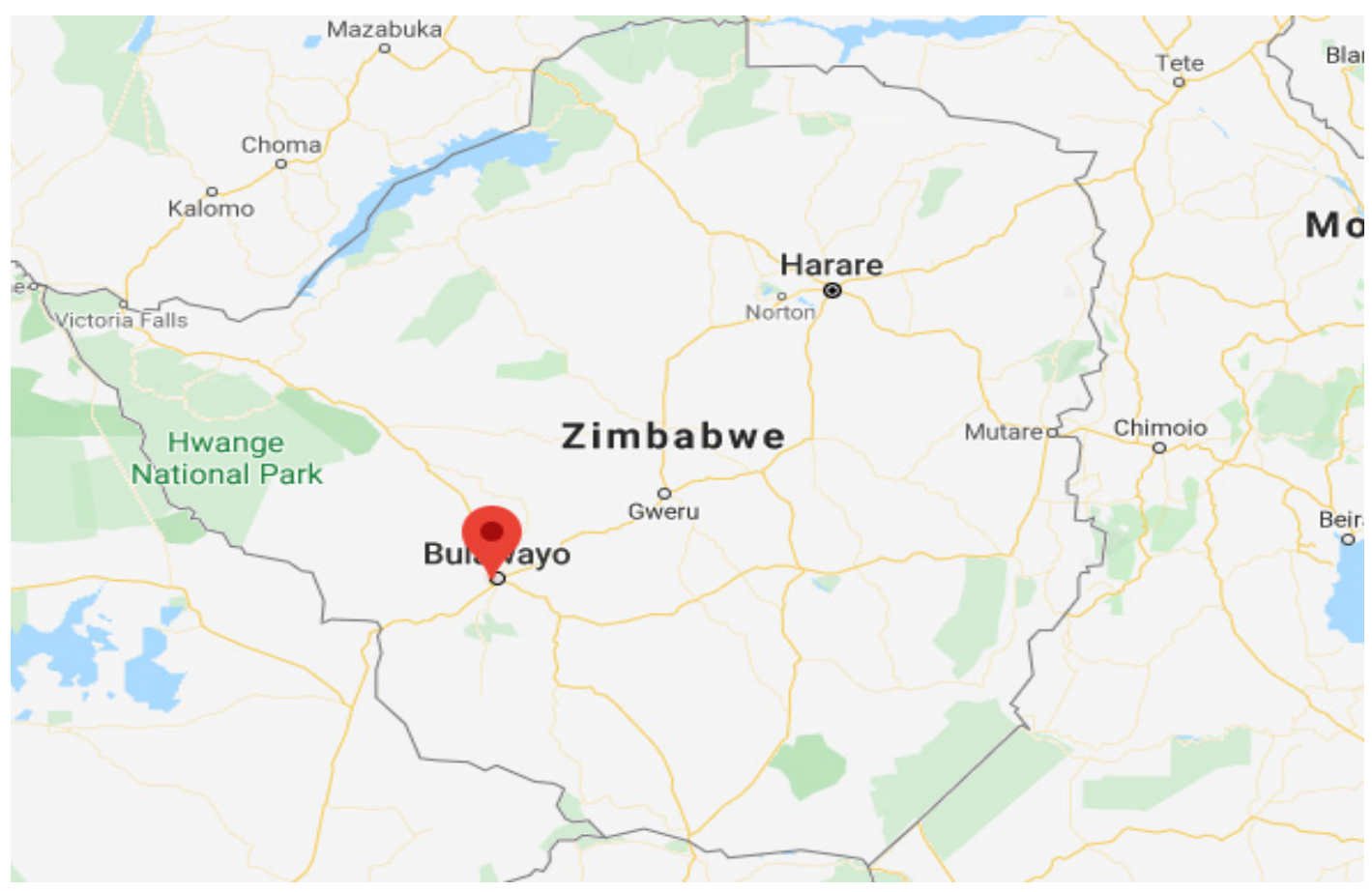

Map 1. Location of Bulawayo, Zimbabwe

Source: Google Maps

Bulawayo has a population of 738,600 and is struggling to find a new future after the devastating loss of life as shown in Figure 1 as well as the collapsing infrastructure and identity during the Mugabe period in the first decade of the $21^{\text {st }}$ century. Figure 1 shows that the death rate in Zimbabwe increased dramatically in the period from 1990 to 2010 . In 1986 the death rate was 8.16 per 1000 population which was low by developing country standards. However, the death rate began the remarkably rapid increase as shown in Figure 1 and peaked in 2004 at 17.95 per 1000 population, one of the worst death rates in the developing world. It then began to improve and reached back to where it had been around 2017 and the latest data from 2019 shows it has reached 7.88 per 1000 population. 


\section{Comparison: Bulawayo, Harare and Zimbabwe Crude Death Rates, 1979 to 2017}

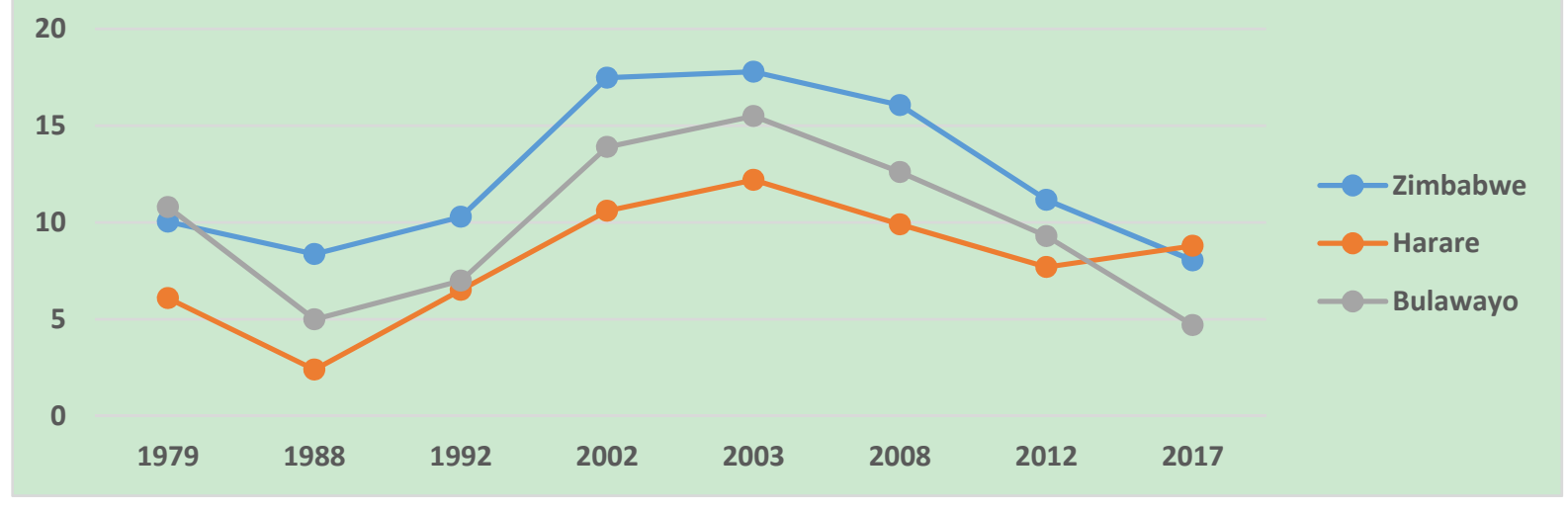

Figure 1. Death rate in Zimbabwe 1979 to 2017

Source: ICDS 2017 - Harare \& Bulawayo (data) \& Source: World Bank - Zimbabwe (data)

What this means for the SDGs is that there has been little chance of sustainable development in Zimbabwe in the period that the world has been working on this approach to economic development. No city or region can achieve anything when such political chaos and economic devastation was causing such high loss of life as depicted on figure 1. This paper is therefore not going to try and seek any other data from that period but instead seek what could be the best way forward for a place like Bulawayo to now try and pursue a programme of development that can start to achieve some localised sustainable development goals. We are focussing on Bulawayo as cities are the focus of 'localization' (Reddy, 2016) and can be expected to take up the SDG 11 project as a matter of priority.

Zimbabwe's post-independence politics of ethnicity has been engineered to destabilise and even derail Bulawayo's development but Bulawayo has a resilience which is now emerging as a way of overcoming such tribal politics with its divisions causing serious economic decline, as evidenced by the death rates shown in Figure 1. Despite the tribal-rooted politics of the ZANU-PF government, Bulawayo has emerged, in the last decades, as one of the best-managed municipalities in Zimbabwe (Bhebe, Bhala, Kadodo, \& Sithole, 2010). However, it has much to do. The city suffers from avoidable water shortages as the national government reneged on development of the Zambezi water project, which could have provided a permanent solution to Bulawayo water challenges. Once the industrial capital of Zimbabwe, water shortages and deliberately skewed regional economic policy has led to the city's de-industrialisation, culminating in high unemployment and ejection of the people of Bulawayo to the diaspora, leaving a city with little hope and a terrible death rate. Informal entrepreneurship now forms the backbone of the city's economy and Bulawayo now seems ready to recreate its future.

The Brundtland Report in 1987 created the term sustainable development to highlight how economic development must include social and environmental goals from concept to reality. Since that time, the world has continued to experience rapid urbanisation. The World Bank shows that urbanization level has increased from $42.3 \%$ urban in 1987 to $55.7 \%$ in 2019; this represents a doubling of the global urban population from 2.102 billion to 4.274 billion (World Bank, 2020). The urban population of Zimbabwe had a similar growth during that period from 2.55 million to 4.72 million, however it slowed to almost zero during the first decade of the $21^{\text {st }}$ century due to substantial economic decline in the last years of the Mugabe Government; it then grew again in the second decade of this century (World Bank, 2020). The paper will see what this period has demonstrated in terms of the SDGs as the economy fluctuated considerably during this period.

The relationship between urban growth, the economy and the SDGs is very complex. The fear is that rapid urbanisation will bring an unsustainable resource exploitation, for example, it is assumed that as rapid urbanisation takes place so the levels of energy use and greenhouse emissions also grow and place pressure on resources and environmental issues increase. However the study by Grossman and Krueger (1995) and later by Peter Newman (2017) has shown that the opposite relationship can actually happen due to decoupling of wealth generation and environmental impacts such as greenhouse emissions. Grossman and Krueger (1995) documented a convex "Ushaped" relationship between environmental degradation and income growth. They suggested that societies do 
show remarkable ingenuity in harnessing new technologies to conserve scarce resources. Accordingly, we can expect that environmental quality might improve if countries develop through substituting cleaner technologies for dirtier ones. It is observed that when countries experience greater prosperity, their citizens become environmentally conscious. This is the goal of sustainable development and hence it has become a non-negotiable and central part of human development. However, when a decade is characterised by a plateau in urbanization the prospects for sustainable development become mixed.

Local government is at the coalface of service delivery and efforts to achieve sustainable development. The SDGs, adopted in September 2015 by 193 United Nations member states, constitute and articulate the global agenda for human development. The operationalisation of SDGs has been fraught with several challenges in developing countries. There is no evidence of any effort of localisation of SDGs by local authorities in Zimbabwe and this is to be expected as shown above.

Zimbabwe is a signatory of most global compacts, however, the country has been 'excommunicated' from the global development institutional framework primarily due to gross and endemic human rights abuses and corruption covering most of the late $20^{\text {th }}$ and early $21^{\text {st }}$ century. Municipalities have not been spared the impact of the collapse of the country's economy. In 2002, the West, mainly led by America and the European Union imposed economic sanctions on the country's kleptocracy to force constitutional and political reforms. Miniscule reforms have taken place. Bulawayo, the country's second largest city is the epitome of the intersection of the politics of ethnicity and economic malaise within this difficult environment. The research project is therefore setup to try and show how Bulawayo could move out of such a framework of despair and create a future based around the SDGs. The fundamental question is how should a city in a developing country structure and complete localised planning for an SDG-based development strategy?

\section{Methodology}

\subsection{Approach}

The research employed a systematic literature review to determine the key approaches to help a city focus its development on the SDGs. A two-stage procedure (planning and implementation) of the systematic literature review entailed four interlinked sub-phases, that is formulation of a study foundation, construction of theoretical and evaluation frameworks, assessment, and lastly the formulation of recommendations and drawing of conclusion as shown in Figure 3. The planning stage consisted of extensive review of literature. Key conclusions of each article were analysed; the results enabled the integration of sources as well as identification of divergence of premises, approaches and findings. The various governance and development management instruments were evaluated on the basis of the metrics informing the evaluation framework. The methodology, like any other, is fraught with challenges, hence, it was critical to identify and mitigate inherent shortcomings.

\subsection{Limitations}

The first apparent shortcoming is related to the delineation of the scope of the research. To manage the huge body of literature, the scope of paper has to be delineated. One of the emerging and most popular area of focus relates to domestication of the global development agenda. Difficult as it is, the study had to make a distinction between domestication and localisation. Apart from the conceptual delineation, there were practical constraints attendant to the methodology. 


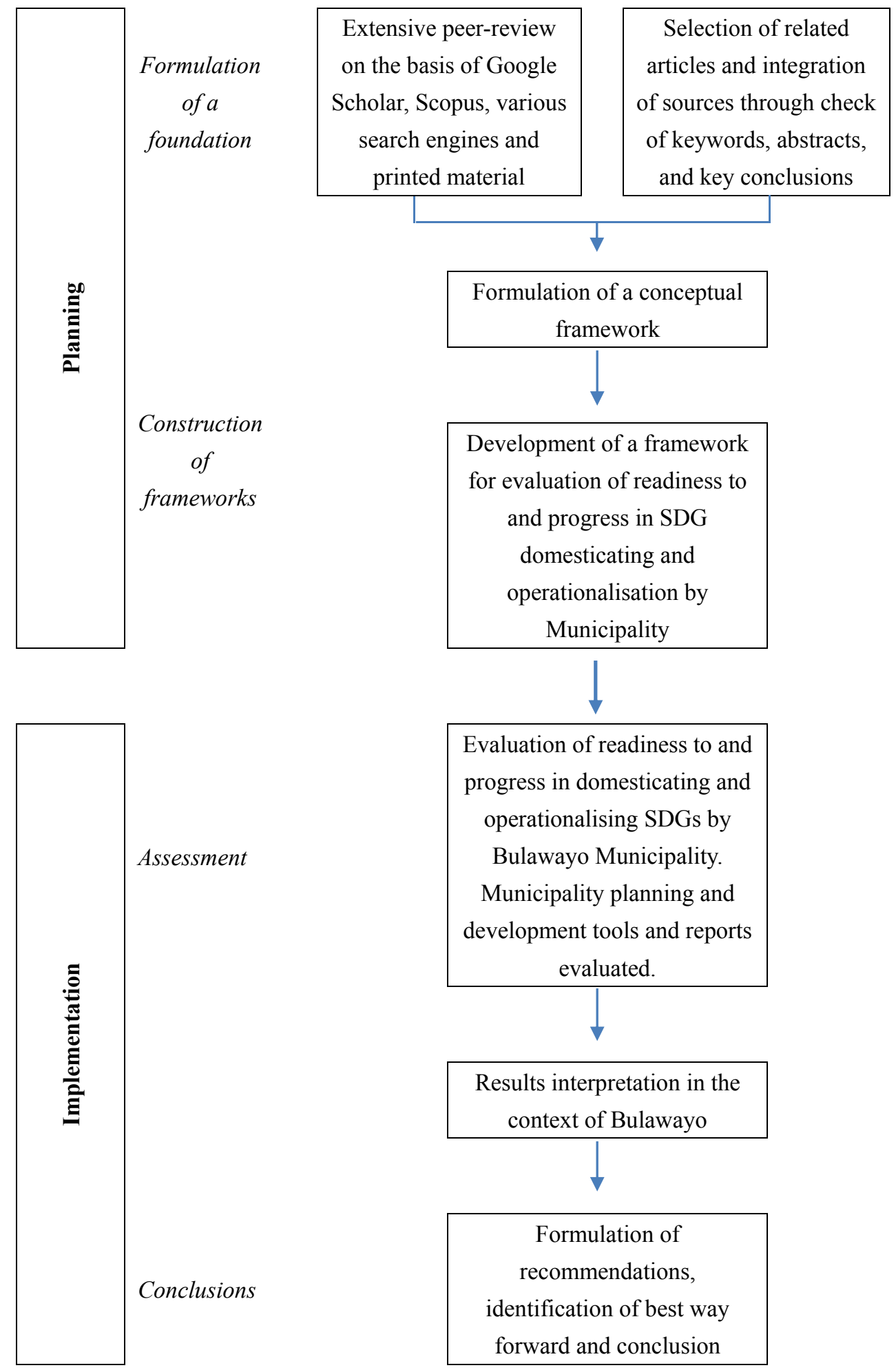

Figure 3. Systematic literature review procedure

One of the key constraints relates to the fact that literature review was mainly limited to journals and other published material that is readily available on public platforms. There is thus a realisation that they might be other written material that are not necessarily published or available on the public domain. Furthermore, the paper has a narrow and well-defined geographic focus that is Bulawayo. Experiences in other municipalities in Zimbabwe and other countries might reveal different results. An additional constraint pertains to the approach of selection of what 
is then deemed relevant literature for review. Despite the limitations of our methodology, we expect that the selected published and official material provides important insights into the subject matter and that the study is representative of the state of domestication and operationalisation of SDGs in Bulawayo. To reduce bias, a wider body of literature was reviewed, and insight reflected on in the context of the study area, Bulawayo.

\section{Systematic Literature Review}

\subsection{Sustainable Development and Cities}

Sustainable development has come to mean many things but has primarily come from the need to modify economic development so that it more fully integrates social and environmental outcomes. There is a realisation that development is a multifaceted and complex phenomenon (Yang, Xu, and Shi (2017).

According to Newman and Kenworthy (1999) and Shaker and Sirodoev (2016) sustainable development for cities needs to be created through the a strategic plan for the city designed to simultaneously improve the economic development, environmental quality, and social equity of the city. In terms of the SDGs, there are five pillars to sustainable development, viz. society, economy, environment, peace, and partnerships. The SDG paradigm has expanded on the traditional tripartite basis of sustainable development, by including the last two that is peace and partnerships as explained by Regan (2002). Cities are thus increasingly adapting governance and development management instruments and practices to guide planning and management of multi-sectoral activities within their jurisdictions. Such localised strategic planning is critical for delivering SDG's.

Equally important to promoting the sustainable development for cities is the evaluation of sustainable development progress as well. Several studies on this task have been conducted. Karatas and El-Rayes (2015) point out that most studies on the evaluation of SD have focussed on analysing (a) the sustainability of construction projects, and (b) the level of service and quality of neighbourhood infrastructure systems such as urban roads. To simplify the evaluation approach, Karatas and El-Rayes (2015) developed the Sustainable Development EvaluationDecision Support System (SDE-DSS). Ironically, their model became overly complicated and thus impractical to operationalise. In response to this, other models were developed. Fehr, Sousa, Pereira, and Pelizer (2004)) formulated a bottom-up management approach to managing cities towards sustainable development. The model is grounded on the focusing of sustainability as a process rather than an outcome though it is hard to imagine this being politically successful in a local area unless the outcomes are also achieved.

Alberti and Susskind (1996) posit that a failed sustainable development strategy manifests in environmental collapse. In essence, environmental collapse, equates to failure by municipalities to discharge their mandates. Service delivery failure will be characterised by pollution, non-collection of refuse or poor refuse management, potholes on roads, sewerage spillages, water bursts and power cuts, amongst other obvious failures that are easily seen by the local population. Unless preventing these 'outcomes' becomes part of an SDG strategy it is unlikely that the city will progress towards a better future in other aspects of SDGs.

Mendes (2000) argued that managing cities towards sustainable development is more than just possession of technical competencies. In that sense, the realisation of sustainable development is primarily dependent on the capacity building with and application of 'soft skills' to the management of cities. Fehr et al. (2004) constructed a model that puts emphasis on appropriate leadership and human capital management to avert environmental collapse.

Technical competence and management skill obviously needs to be combined. A key way to do this is by certifying standards that are both appropriate and yet can enable sustainable development outcomes. Karatas and El-Rayes (2015) reflected on the importance for cities to think of sustainable development when they are setting out their planning for buildings; they suggest that by building cities that have the capability to install renewable energy technologies with energy storage capabilities then all the economic, environmental and social goals can be reached. These buildings should be energy efficiency certified and the same approach needs to facilitate the economic and sustainable use of water. The cities' buildings should not only be energy efficient certified, but also the cities themselves should be designed to qualify as sponge cities. According to Yang et al. (2017) they defined sponge cities as the cities that act like sponges, can absorb, purify, and retain rainwater. These approaches that integrate resource consumption into planning can be applied across the whole of the planning system.

\subsection{Leapfrogging Towards Sustainable Development in the Next Economy}

The first era of the sustainable development paradigm has been very slow, however it is possible that it may accelerate in the coming era. The next global economy has been called the Third Industrial Revolution by Rifkin (2013), the Fourth Industrial Revolution by Klaus (2016) and the Sixth Economic Wave by a range of academics (Peter. Newman, 2020) building on the economic wave theory of Schumpeter (1939) and Kondratief (1984). The 
key idea in all of these is that technological change can enable a new economy once the other one before it collapses. This is certainly the global situation and certainly is doubly the case with Bulawayo as it saw the collapse of its industrial base in the first decade of the $21^{\text {st }}$ century not the 2020's as is happening now across the world.

For the developing world there are possibilities that they can leap-frog into the next economy (Ndlovu \& Newman, 2020). They are not confronting the problems of the previous economy in terms of massive institutional inertia and lobbying from those who have the most to lose, like fossil fuel companies. The literature on leap-frogging suggests that this is possible if the cities and nations involved are able to create the kind of supportive governance base that can welcome and enable demonstrations (Conroy \& Berke, 2004; Ndlovu \& Newman, 2020). The literature review therefore begins to focus on what are the detailed outcomes being sought by cities.

\subsection{Evaluation of Progress by Cities Towards Sustainable Development}

Zinkernagel. R, Evans. J, and Neij (2018) postulate that "although cities have been using indicators for a long time it is only in the last decades that attempts have been made to collate indicators into sets that reflect the many different aspects required to assess the sustainability of a city". The UN Global Compact, the Global Reporting Initiative and the World Council for Business and Sustainable Development (2020) have produced an SDG Compass that sets out ten pages of tools to assist nations in delivering the SDGs. According to Wilson, Tyedmers, and Pelot (2007) some key commonalities exist in a number of the various cited evaluation frameworks. These are mostly in the form of indicators relating to economic productivity and progression, ecological footprint, biocapacity, (citizen) wellbeing, and human development. The politics of or affecting the city is an area that some of the frameworks shy away from or rather peripheralize. This proves that measuring progress towards sustainable development of a city is more than a straightforward technical process. Fehr et al. (2004) used the indicators below to test the environmental sustainability of Toribate city:

$\circ$ Demographic density and evolution
$\circ$ Public transportation
$\circ$ Solid waste handling
$\circ$ Liquid effluent handling
$\circ$ Air monitoring
$\circ \quad$ Fresh water supply
- Public education
- Public health care
○ Cultural manifestations
- Energy supply
○ Park maintenance
$\circ \quad$ Land use and resource preservation

Fehr et al. (2004) concluded that a city that is developing sustainably is one that is in control of the cited indicators.

\subsection{Public Participation and SDG Outcomes}

Fehr et al. (2004) posit that sustainability cannot be bought, that it is a philosophy of life that must be conquered and acquired. They posit that the challenge to get the sustainability plans successfully implemented or the adoption of this new "philosophy" lies purely on making the citizens accept these SD indicators and be involved in their achievements. Hence, their view that this task requires very competent and innovative managers who will be able to manage people with creative methods. They concluded that this management challenge has become an educational task. Competent managers should know to involve all relevant stakeholders at the beginning of developing the SD plans for the cities. A collaborative planning process minimises disputes by getting issues and concerns onto the discussion agenda for resolution. Conroy and Berke (2004) reaffirm this when they suggest that "when people are involved in the decision-making process, they are more likely to be supportive of the implementation of the initiative". Potapchuk, Crocker Jr, and Schechter (1999) echoed this notion by inferring that "participation helps to build social capital in a community, which in turn strengthens the community".

Given that sustainable behaviour is a day by day undertaking, local participation becomes very crucial to support this philosophy of lifestyle. It is the communities themselves that will have to live sustainably and responsibly hence public involvement at the onset of the plan is crucial. Innes (1996) refers to this as participatory democracy as a means for democratic discourse. Numerous studies have also shown that local capacity and participation plays an important role in promoting successful introduction and implementation of various community-based plans. Possibly the most significant is the political and community support to the planning process. Political support helps to increase community interest. Local participation that involves local resource commitment is documented to be crucial for the adoption and implementation of community-based initiatives such as SD programmes. Conroy and Berke (2004) tested the significance of the three dimensions of the plan-making process:

- Political support for sustainable development within communities, 
- Efforts designed to support public participation,

- Resources committed to plan preparation.

The tests proved that the presence of the state in the promotion of such initiatives is extremely important and significant. The tests also indicated that the participation breadth was important and statistically significant. An involvement of the community in the initial stage of formulating the plans is a good undertaking, for it builds harmony and minimises the resistance downstream. According to Conroy and Berke (2004) "Increased participation breadth means an increase in the variety of opinions, concerns, and expertise that will be represented in the participation process". The importance of public involvement in the planning process is also well documented in various studies of planning. The involvement of the government and the public in the sustainable development planning process promotes both the top-down and bottom-up participation. Hence, a key conclusion from this background literature is that state mandates and public participation are key to integrate in promotion of the sustainable development agenda.

\subsection{Framework for Assessment for City's Potential to Localise and Achieve SDGs}

The systematic review of literature has provided a conceptual assessment framework that can be used to assist with localisation of SDG's in a city (Figure 2). The framework provides both a process path as well as articulates the substantive domains of focus with respect to assessing/evaluating a municipality's readiness in localisation and progress in operationalisation of SDGs.

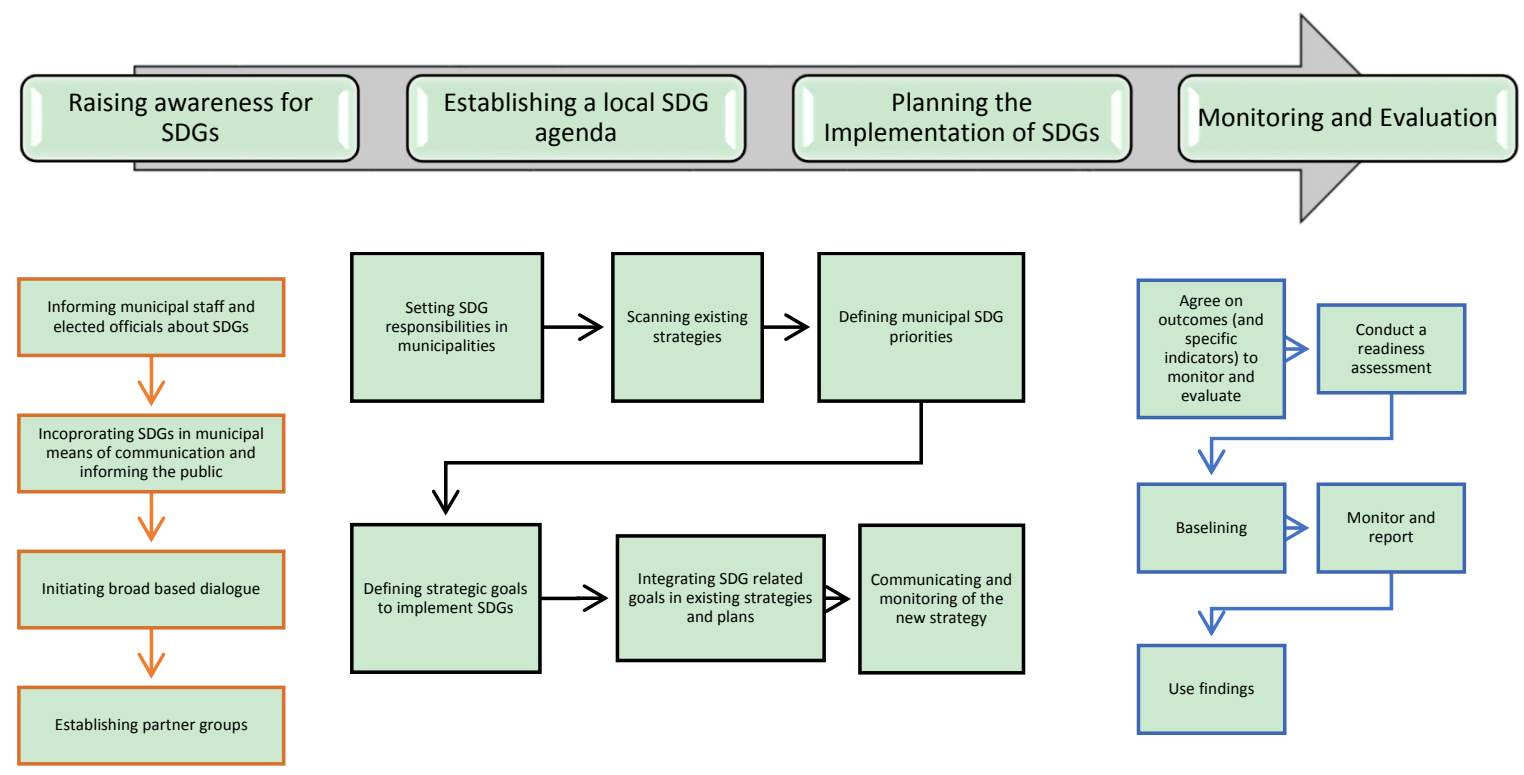

Figure 2. Framework Guiding Evaluation of SDG Localisation

Source: Top part adapted from UN; M\&E component, Own

Awareness raising forms the cornerstone for localisation of SDGs. Building awareness focuses on the broad array of stakeholders, interest groups and the affected groups. As highlighted in the bottom part of Figure 2, dialoguing amongst the stakeholders is critical and should, if effectively facilitated, culminate in establishment of partnerships for the purposes of localisation of SDGs. Agenda setting heralds the start of tangible work by the various partners towards identifying key development priorities against the backdrop of the global development agenda, as enunciated by the SDGs. Role clarification is therefore a pre-requisite. The conceptual framework accentuates the need to undertake thorough planning, and to avoid a cosmetic process of simply reworking development instruments to reflect the language associated with SDGs. The planning is akin to but not necessarily the same as the technical process associated with the corporate strategic planning phase of PESTLE analysis which is conventional strategic planning, i.e. political, economic, social, technological, legal and environmental domains. A key difference is the need for community engagement to enable it to go forward with broad acceptance. SDG planning in cities provides the foundation for identification and prioritisation of a municipality's SDG priorities, and formulation of strategic goals and targets along with a process to deliver the plan for the local context.

The backbone of the framework emphasises the need to align the process outcomes to the key themes addressed 
by SDG 11:

- Planning and managing for sustainability, that is ensuring mutually conducive and beneficial interface between social, economic and environmental subsystem

- Appropriately planned and managed human settlements

- Access to affordable housing

- Infrastructure investments

- Sustainable transportation

- Access to services

- Culture, natural heritage, and public places

- Sustainable buildings

- Disaster prevention, risk reduction and disaster recovery

- Inclusivity (that is age, gender, and disability) and community resilience

Once the canvas of strategic goals and targets is knit together, a process of ensuring alignment and integration of SDGs into governance and development management instruments follows. Communication is key and should permeate the entire process, that is from awareness building to operationalisation of governance and development management instruments which encapsulate the localised (global) development agenda. Communication with the community and all stakeholders will be critical.

The framework utilises and emphasizes the need for results-based leadership and management. Instead of the conventional monitoring and evaluation approach, which is oriented towards technical reporting, a developmental approach, that is Results-based Monitoring, Evaluation, Accounting and Learning (MEAL) approach - is followed as envisaged by Macclune, McGinn, Asif, and Venkateswaran (2017). Baselining, that is establishing the conditions prior to operationalisation of localised SDGs, is critical. It provides the departure point for measurement of progress or lack of, throughout the processes of implementation of the localised SDGs' frameworks. The benefits of the MEAL approach in the implementation of localised SDGs is that it:

- Informs resource allocation decisions

- Provides informed perceptive in problem diagnosis, including identification of emerging challenges and externalities

- Informs decision making on competing alternatives and thus identification of the best alternatives

- Encourages and supports innovative thinking and actions, and

- Fosters consensus on the causes of problems, desired outcomes, and solutions to the same

The advantage of the MEAL approach is its ability to continuously provide the information on progress in the operationalisation of SDGs at any given time. The main focus is on outcomes that will demonstrate whether success has been achieved. This is undertaken with a dual intent, to learn and to improve. This enables continuous improvement which will be critical to any city, especially one trying to be a leader in a complex and difficult development environment.

With this framework, the paper will now examine how it has been applied to Bulawayo.

\section{Results: How does the SDG Localisation Framework Apply to Bulawayo?}

This paper seeks to find how the SDG Localisation Framework can help provide an SDG-based future for the City of Bulawayo as shown in Figure 2. Most importantly it seeks to provide answers to the 4 key questions embedded in the framework, namely:

1) What is the extent of awareness for SDGs within the City?

2) Is there an established SDGs agenda in the City of Bulawayo?

3) What measures and steps have been taken, if any, to operationalise the SDG 11 by Bulawayo City Council?

4) Is there a system for the monitoring and evaluation of the operationalisation of SDGs in the City, and if so, what is its efficacy?

\subsection{Staff Awareness}

City Council's planning staff have been exposed to and on a number of occasions had opportunity to engage on 
the subject of sustainable development, more so within the current SDG context. To ensure that awareness and appreciation for SDGs permeates to the city at large, the following has been undertaken:

- A workshop on SDG was conducted for the Councillors and the civic community (Oosterom, 2019);

- Female councillors have received training on SDGs in order to capacitate them as women in leadership roles;

- Gender equity and social inclusion awareness campaigns on gender based violence, Sexual and Reproductive Health Rights (SRHR ) and service delivery campaigns; and

- Gender Mainstreaming initiatives by organisations such as Gender Links, ZWRCN, WILD and Women Coalition of Zimbabwe and CSO WASH incorporate SDGs.

One of the expected main outcomes of the workshop was that the Councillors would further engage their different constituencies on the subject, that is SDGs, and their implications for the city's current and future development. Thus the SDG planning process has been linked into the service delivery process heightening awareness across the municipality. It would appear therefore that there is a high level of awareness of the SDGs within Bulawayo City Council.

\subsection{SDG Agenda}

It is evident that the City of Bulawayo has made SDGs central to its developmental agenda. The City of Bulawayo is not only driving the SDG agenda through its service delivery programmes but has established how the SDGs relate to all the main legislative tools guiding development in the city. Table 2 summarises the key instruments informing the City of Bulawayo's Master Plan 2019-2034. The City of Bulawayo's Master Plan - its key strategy document - has thus been developed to embrace and promote the SDGs' agenda as evidenced in Table 2. The Report of Study that will inform the production of the Master Plan's written statement explicitly states that the City's new Master Plan is being aligned to the SDGs. As a result, during the preparation of the written statement due cognisance will be given to the SDGs. The SDG agenda appears therefore to be incorporated into the localised planning of future development in the city (City of Bulawayo, 2020a, 2020b).

Table 2. Development, policy and legislative frameworks guiding the development of the City of Bulawayo Master Plan $2019-2034$

Urban Councils Act (Chapter 29:15)

National Housing Policy 2012

Sustainable Development Goals

Regional Town and Country Planning Act, Chapter 29:12 of 1976 (Revised 1996)

Urban Councils Act, 1995, No. 24 of 1995

Environmental Management Act, Chapter 20:27 of 2002

Environmental Impact Assessment and Ecosystems Protection Act, No I 7 of 2007

Environment Management Act (Environmental Impact Assessment \& AMP; Ecosystems

Protection) Regulations, Chapter 20:27 of 2007

Regional Town and Country Planning Act, Statutory Instrument 216 (Use Group

Regulations) of 1994

Mines and Minerals Act, Chapter 21:05 of 1961

Zimbabwe Interim Poverty Reduction Strategy Paper (I-PRSP) 2016-2018

Forest Act, Chapter 19:05 of 1949

Education Act, Chapter 25:04 of 1987

Source: City of Bulawayo (2020b, p. 11)

\subsection{Steps to Operationalise}

Below is a summary of some of the strategic priorities and processes reflected in the draft Master Plan, Corporate Strategy and other policy documents showing how steps are being taken to deliver the SDG's outlined in these plans. These are very early days as the municipality begins to set up programs across its service delivery and 
planning system. Bulawayo used to be the industrial hub of Zimbabwe but since the 1980s it has experienced some massive de-industrialisation. Like the rest of the country, the informal sector has become the backbone of the economy. Efforts at providing an enabling environment for informal sector operations have been done through the establishment of industrial incubators, designation of sites for informal sector operators to operate from as elaborated by the City of Bulawayo (2020b, p. 59). These efforts are meant to ensure that people can make a living by indirectly addressing Goal 1 (City of Bulawayo, 2000). With respect to SDG 2, the City has developed an Urban Agricultural Policy to promote and guide urban agriculture and contribute to food security (City of Bulawayo, 2010), (City of Bulawayo, 2020b, pp. 60-62).

The City has for the past two decades allocated sites for garden allotments to assist the elderly and destitute. Health issues are also at the centre of the City's strategic priorities in line with SDG 3. As demonstrated by the City of Bulawayo (2020b, p. 175) the provision of health facilities in all the neighbourhoods is meant to improve the health and wellbeing of the community . In addition, the City of Bulawayo (2020a, p. 24) shows there have been an increase in private hospitals and surgeries, approved by the Bulawayo City Council in the residential areas in line with its corporate strategy of promoting the private sector to lead in the building of public infrastructure. Outreach services are being provided to supplement inadequate health service delivery in areas such as St Peters, Aisleby Farm, Emganwini, Nketa and Cowdray Park on a monthly basis. According to the City of Bulawayo (2020b, pp. 171-191) all these are being undertaken as part of the core function of the Municipality of providing primary health care.

The undertakings by the City of Bulawayo (2020b, p. 40) do indicate that the Municipality has paid a lot of attention to issues of preserving and protecting the natural environment and climate change, as per the provisions of SDG 13 and 15. The City is working closely with the Environmental Management Agency (EMA). Major projects (housing, commercial and industrial developments) in the city are being undertaken subject to the preparation of a prospectus and detailed EIA report. In addition, environmental audits are being undertaken as indicated by the City of Bulawayo (2020b, p. 282). For example the dumpsite in the city was developed in 1994 without the benefit of an EIA. In an effort to ensure that good environmental management practices are in place, monitoring boreholes have been sunk and leachate from the ponds is being collected to ensure that there is little/no pollution (City of Bulawayo, 2020b, p. 199).

Education is crucial in the drive towards a sustainable city, as per SDG 4. The provision of primary educational facilities constitutes a major function of the city. In the new residential neighbourhoods the city provides primary educational facilities as revealed by the City of Bulawayo (2020b, p. 141). According to the City of Bulawayo (2020b, pp. 131-140) additional Early Childhood Development facilities have been established to improve education outcomes. Furthermore, the city has made provision of land for private school development which has assisted in the provision of additional educational facilities (City of Bulawayo, 2020b, p. 151). Partnerships with the private sector to supplement the council's effort to provide public services forms part of the city's future corporate strategy focus as documented by the City of Bulawayo (2020a, p. 16 \& 20).

Gender-sensitive development is also within the purview of the Municipality, as per SDG 5, hence the formulation of a gender policy. One of the main intervention speaking to SDG 5 is the 365 days of activism against Gender Based Violence (GBV) which is led by the Gender Desk within the Municipality (City of Bulawayo, 2017). A critical issue linked to gender has been the historic challenge of resolving the water shortage. The Municipality has taken on-board SDG 6 to plan for clean water and sanitation in a sustainable manner. Major rehabilitations works of the water works for the city from the dams have been undertaken as explained by the City of Bulawayo (2020b, p. 256). In addition, the Bulawayo Water and Sewerage Services improvement project (BWSSIP) is underway.

These cited examples above are part of initiatives meant to contribute towards the attainment of SDGs. This includes the streamlining of the City's planning and budgeting processes to align to and give prominence to each of the 17 SDGs. It is clear that the City is premising its work on sustainable service delivery and resource management. This is clear considering that departmental plans now encapsulate the SDGs as revealed by the City of Bulawayo (2020b, p. 11). All departmental plans must demonstrate alignment to and how they contribute to specific SDGs. This includes localisation of strategic objectives and targets, within the framework of the SDGs.

The city is involved in various public relation activities in an effort to enhance the relationship between the Local Authority and the community. It is hoped that the City will leverage on its twinning relations with Aberdeen (United Kingdom) and Durban - Ethekwini (South Africa) to learn and exchange its experiences and thus improve on its efforts towards urban sustainability. Sustainable development is at the heart of the City's development efforts. 


\subsection{Monitoring and Evaluation (M\&E)}

The SDG's form part of reporting across different forums of accountability and at different intervals in the municipality. However, the City's M\&E system identifies funding of development programmes and projects as a major challenge. However, the City identifies research and investing in innovative ways of doing things as key enablers towards meaningful work towards SDGs. In this regard, the City has moved to enhance its operations through eGovernance.

\section{Conclusion}

Notwithstanding the exponential growth of literature on SDGs, there is little focus on the readiness of and progress by local government in the localisation of SDGs. The paper has used a systematic literature review of research on municipalities in relation to implementation of SDGs. A multi-criteria framework for planning and managing towards the achievement of SDGs has been developed using a four-step process: raising awareness of SDGs; establishing a local SDG agenda; planning implementation of the SDG agenda; and, monitoring and evaluation.

The SDGs are a call to end poverty, protect the planet and ensure that people enjoy peace and prosperity by 2030 . The City's mandate is to ensure good governance, provide services as well as social and physical infrastructure. It is important to see that the collapse of Bulawayo's public transport and water distribution systems, once the envy of and benchmark for many local authorities in the country, provides a poignant reminder that past glory is meaningless in addressing present challenges. There is therefore a need for continued awareness building and capacity building of planning staff, elected officials and interest groups within the City. In this regard, there is need for forums involving Council management and Councillors to discuss SDGs - what the city is doing or can do towards the attainment of these universally agreed goals. People could be having knowledge from other forums funds could be sourced from UNDP - the lead UN development agency for awareness workshops to council management, councillors and the community. There is a need to invest a lot of effort in building community level awareness and involvement in the work towards SDGs. This could be facilitated through grassroots workshops and meetings at the ward level.

Infrastructure projects can be developed in partnership with private sector financing to enable major leap-frogging in technology to happen.

The massive increase in death rates from 2000 to 2010 due to the HIV pandemic, political chaos and economic disintegration of that period has made the work on SDGs very difficult for the City of Bulawayo. To come out of that period of economic and social collapse there was little to help cities like Bulawayo to grasp the opportunity for an SDG-based development focus. Nevertheless the city has rapidly advanced through the localised planning process and are beginning to show they can begin to deliver the SDGs.

Through the application of the evaluation framework, the article has indeed shown that Bulawayo explicitly demonstrates the pathway to sustainable development. However, the city will need to avoid continuing the preoccupation with issues from the previous era - corruption, nepotism and even trivia (e.g. changing street names) to the detriment of addressing real development issues. Help is needed to update the planning system and to create an innovative management culture that can ensure SDG outcomes and potentials for using leap-frog technology are the priority.

There is ample room to apply the evaluation framework (developed for this case study) to other cities in the developing world.

\section{Acknowledgements}

The authors declare no conflicts of interest regarding the publication of this paper.

\section{References}

Alberti, M., \& Susskind, L. (1996). Managing urban sustainability: An introduction to the special issue. Environmental Impact Assessment Review, 16(4), 213-221. https://doi.org/10.1016/S0195-9255(96)00070-4

Bhebe, C., Bhala, T., Kadodo, W., \& Sithole, N. (2010). Customary law of inheritance in traditional Ndebele families as depicted in selected Ndebele works of art. Zimbabwe Journal of Educational Research, 25(2), 343-356. Retrieved from https://opendocs.ids.ac.uk/opendocs/handle/20.500.12413/8918

Brundtland Commission. (1987). Our Common Future. Oxford University Press. Retrieved from https://sustainabledevelopment.un.org/content/documents/5987our-common-future.pdf

City of Bulawayo. (2000). Youth Policy. Retrieved from http://citybyo.co.zw/Downloads/GetPolicy?fileShortName=youth_policy.pdf 
City of Bulawayo. (2010). URBAN AGRICULTURE POLICY - CITY OF BULAWAYO. Retrieved from http:/citybyo.co.zw/Downloads/GetPolicy?fileShortName=Urban_Agriculture_Policy.pdf

City of Bulawayo. (2017). Gender Policy. Retrieved from http://citybyo.co.zw/Downloads/GetPolicy?fileShortName=BULAWAYO_CITY_COUNCIL_GENDER_P OLICY_\%20JULY_2017.pdf

City of Bulawayo. (2020a). Corporate Strategy 2020-2024. The City of Bulawayo, (2020). Retrieved from http://citybyo.co.zw/Downloads/GetPolicy?fileShortName=BCC_strategy_document_Final.pdf

City of Bulawayo. (2020b). Report of Study - Master Plan 2019-2034. The City of Bulawayo, (2020). Retrieved from http://citybyo.co.zw/Downloads/Policies

Conroy, M. M., \& Berke, R. P. (2004). What makes a good sustainable development plan? An analysis of factors that influence principles of sustainable development. Environment and Planning A, 36, 1381-1396. https://doi.org/https://doi.org/10.1068/a367

Fehr, M., Sousa, K. A., Pereira, A. F. N., \& Pelizer, L. C. (2004). Proposal of Indicators to Assess Urban Sustainability in Brazil. Environment, Development and Sustainability, 6(3), 355-366. https://doi.org/10.1023/B:ENVI.0000029914.82071.6e

Grossman, G. M., \& Krueger, A. B. (1995). Economic Growth and the Environment. The Quarterly Journal of Economics, 110(2), 353-377. https://doi.org/10.2307/2118443

Innes, J. E. (1996). Planning Through Consensus Building: A New View of the Comprehensive Planning Ideal. Journal of the American Planning Association, 62(4), 460-472. https://doi.org/10.1080/01944369608975712

Kamete, A. Y., Sidambe, M., \& Ndubiwa, M. M. (2000). Managing the Interface Between Urban Councils and Surrounding Rural District Councils in Zimbabwe: The Case of the City of Bulawayo and Umguza Rural District Council. Municipal Development Programme, Harare. Retrieved from http://eprints.gla.ac.uk/68237/

Karatas, A., \& El-Rayes, K. (2015). Evaluating the performance of sustainable development in urban neighborhoods based on the feedback of multiple stakeholders. Sustainable Cities and Society, 14, 374-382. https://doi.org/10.1016/j.scs.2014.05.011

Klaus, S. (2016). The Fourth Industrial Revolution. Retrieved from https://www.weforum.org/about/the-fourthindustrial-revolution-by-klaus-schwab

Macclune, K., McGinn, C., Asif, F., \& Venkateswaran, K. (2017). Design, Monitoring, Evaluation, and Learning for Climate Resilience-A Guidance Paper for the Philippines.

Mbiba Beacon, \& Ndubiwa Michael. (2008). Decent work in construction and the role of local authorities: the case of Bulawayo city, Zimbabwe. Retrieved from http://eprints.lse.ac.uk/3015/

Mendes, R. (2000). Helthy City: an interdisciplinary and intersectorial experience. Revista de Administração Pública, 34(6), 47-61. Retrieved from https://link.library.curtin.edu.au/gw?url=https://search.proquest.com/docview/1643151272?accountid=1038 2

Ndlovu, V., \& Newman, P. (2020). Leapfrog Technology and How It Applies to Trackless Tram. Journal of Transportation Technologies, 10(3). https://doi.org/10.4236/jtts.2020.103013

Newman, P. (2017). Decoupling Economic Growth from Fossil Fuels. Modern Economy, 8, 791-805. https://doi.org/10.4236/me.2017.86055

Newman, P. (2020). COVID, CITIES and CLIMATE: Historical Precedents and Potential Transitions for the New Economy. Urban Sci, 4(3). https://doi.org/10.3390/urbansci4030032

Newman, P., \& Kenworthy, J. (1999). Sustainability and cities : overcoming automobile dependence / Peter Newman, Jeffrey Kenworthy. Washington, D.C.: Washington, D.C.: Island Press.

Oosterom, M. (2019). The Implications of Closing Civic Space for Sustainable Development in Zimbabwe. Mimeo, IDS and ACT Alliance Retrieved from https://assets.publishing.service.gov.uk/media/5e57dfe486650c53b49c689b/Zimbabwe_civic_space_sustain able_development_pdf

Potapchuk, W. R., Crocker Jr, J. P., \& Schechter, W. H. (1999). The Transformative Power of Governance. National Civic Review, 88(3), 217-248. https://doi.org/10.1002/ncr.88307 
Reddy, P. S. (2016). Localising the sustainable development goals (SDGs) : the role of local government in context. African Journal of Public Affairs, 9(2). Retrieved from http://hdl.handle.net/2263/58190

Regan, C. (2002). Development in an Unequal World. 80:20 Educating and Acting for a Better World. Ireland.

Rifkin, J. A. (2013). The third industrial revolution : how lateral power is transforming energy, the economy, and the world / Jeremy Rifkin (First Palgrave Macmillan paperback edition.. ed.): New York : Palgrave Macmillan.

Shaker, R. R., \& Sirodoev, I. G. (2016). Assessing sustainable development across Moldova using household and $\begin{array}{lllll}\text { property } & \text { composition indicators. Habitat International, }\end{array}$ https://doi.org/10.1016/j.habitatint.2016.03.005

UN-Habitat. (2016). World Cities Report 2016: Urbanization and Development - Emerging Futures. Retrieved from https://unhabitat.org/world-cities-report

United Nations. (2015). Sustainable Cities and Communities. Retrieved from https://www.un.org/sustainabledevelopment/cities/

United Nations Global Impact. (2020). DuPont Economic, Environmental, and Social Performance Data in the Global Reporting Initiative Format May 2004. Retrieved from https://www.unglobalcompact.org/participation/report/cop/create-and-submit/detail/2564

UNSDGs. (2015). United Nations Sustainable Development Summit 2015. Retrieved from https://sustainabledevelopment.un.org/post2015/summit

Wilson, J., Tyedmers, P., \& Pelot, R. (2007). Contrasting and comparing sustainable development indicator metrics. Ecological Indicators, 7(2), 299-314. https://doi.org/10.1016/j.ecolind.2006.02.009

World Bank. (2020). Urban population growth (annual \%). World Bank. Retrieved from https://data.worldbank.org/indicator/SP.URB.GROW

Yang, B., Xu, T., \& Shi, L. (2017). Analysis on sustainable urban development levels and trends in China's cities. Journal of Cleaner Production, 141, 868-880. https://doi.org/10.1016/j.jclepro.2016.09.121

Zinkernagel. R, Evans. J, \& Neij, L. (2018). Applying the SDGs to Cities: Business as Usual or a New Dawn? Sustainability, 10(3201).

\section{Copyrights}

Copyright for this article is retained by the author(s), with first publication rights granted to the journal.

This is an open-access article distributed under the terms and conditions of the Creative Commons Attribution license (http://creativecommons.org/licenses/by/4.0/). 